\title{
EFFECT OF ASCORBIC ACID AND/OR ALPHA-TOCOPHEROL FORTIFICATION ON SEMEN QUALITY, METABOLIC PROFILE, ANTIOXIDANTS STATUS, AND DNA OF ROOSTERS EXPOSED TO HEAT STRESS
}

\author{
Y. A. Attia ${ }^{1 *}$, B. M. Abou-Shehema ${ }^{2}$, A. A. Abdellah ${ }^{2}$, O. M. Aly ${ }^{3}$ and Asmaa Sh. El-Naggar ${ }^{4}$ \\ ${ }^{1}$ Arid Land Agriculture Department, Faculty of Meteorology, Environment and Arid Land Agriculture, King Abdulaziz \\ University, P.O. Box 80208, Jeddah 21589, Saudi Arabia \\ ${ }^{2}$ Department of Poultry Nutrition, Animal Production Research Institute, Agriculture Research Center, Ministry of \\ Agriculture and Land reclamation, Egypt \\ ${ }^{3}$ Department of Poultry breeding, Animal Production Research Institute, Agriculture Research Center, Ministry of \\ Agriculture and Land reclamation, Egypt \\ ${ }^{4}$ Animal and Poultry Production Department, Faculty of Agriculture, Damanhour University, Damanhour, Egypt \\ ${ }^{*}$ Corresponding author e-mail: yaattia@kau.edu.sa
}

\begin{abstract}
This study investigates the influence of heat stress (HS) and vitamin C (VC) and/or vitamin E (VE) on semen quality, biochemical constituents of seminal and blood plasma, antioxidant status and jejunum and ilium deoxyribonucleic acid (DNA) of roosters. Forty-five, 32-week-old roosters were divided into five groups of nine replicates. One group was kept under a thermoneutral environment, whereas the other four were kept under HS. One of the four groups served as an unsupplemented HS group and was fed the basal diet only. The other three HS groups were supplemented with VC (200 $\mathrm{mg} / \mathrm{kg}$ ascorbic acid and/or VE $150 \mathrm{mg} / \mathrm{kg} \alpha$-tocopherol acetate). Vitamins fortification completely restored sperm liveability, semen $\mathrm{pH}$, fertility, seminal plasma total protein and globulin to the control level. Vitamins fortification completely recovered seminal plasma and blood plasma total antioxidant capacity (TAC) and malondialdehyde (MDA), red blood cell (RBCs), haemoglobin (Hgb), packed cell volume (PCV), white blood cells (WBCs), blood plasma glucose, lipid profiles, liver enzymes, and renal function. Heterophil/lymphocyte $(\mathrm{H} / \mathrm{L})$ ratio was totally restored following VE fortification. Vitamins fortification significantly increased jejunum and ileum DNA compared with the HS group, with VC inducing a complete recovery. In conclusion, either $200 \mathrm{mg} / \mathrm{kg} \mathrm{VC}$ or $150 \mathrm{mg} / \mathrm{kg} \mathrm{VE}$ improved semen quality, fertility, seminal plasma and blood biochemistry and haematology of HS roosters, with the VE group yielding greater immunity.
\end{abstract}

Keywords: Roosters. Heat Stress. Semen Quality. Vitamin C. Vitamin E.

https://doi.org/10.36899/JAPS.2020.2.0051

Published online March 02, 2020

\section{INTRODUCTION}

Heat stress (HS) has been shown to have adverse effects on animal productivity and leads to increasing reactive oxygen species (ROS) production, stimulating the secretion of catecholamines and corticosterone and initiating the peroxidation of lipid in cell membranes (Khan, 2011; Attia et al., 2017; Conte et al., 2018). The balance between antioxidants reserves (biomolecules, enzymes, vitamins) and oxidants (production of free radicals) plays a major role in controlling the adverse impact of HS and limiting ROS production (Khan et al., 2012a;b; Kutlu et al., 2019).

The HS has been shown to have a negative effect on testes and testicular function through inhibition of intracellular ion exchange (Ayo et al., 2011; Khan et al., 2014; Chen et al., 2015), as well as influencing the ejaculate volume, concentration and motility of sperm (Turk et al., 2016). The adverse impact of HS on performance, semen quality, and fertility of animals was observed when the air temperature was increased above $27^{\circ} \mathrm{C}$ (Biswas et al., 2009). High levels of polyunsaturated fatty acids, including arachidonic and docosatetraenoic acids, have been reported in the cell membrane of avian spermatozoa (Surai et al., 2001). Hence, avian sperm are very sensitive to ROS, which cause male infertility (Zaniboni et al., 2006). Oxidative damage of spermatozoa can decrease motility and fertility (McDaniel et al., 2004). Moreover, HS was shown to damage the spermatozoal deoxyribonucleic acid (DNA), resulting in abnormal mitotic division during spermatogenesis. This could affect spermatozoal parameters including low sperm number, viability and motility with associated DNA impairment. Interestingly, these abnormal spermatozoal parameters were observed among spermatozoa developed from spermatids in testis exposed to HS (Ayo et al., 2011). This could lead to the development of abnormal spermatozoa, which 
consequently may not have the ability to achieve fertilisation (McDaniel et al., 2004).

There are several approaches to relieve the negative influences of HS. Antioxidants including vitamin $\mathrm{C}(\mathrm{VC})$ and vitamin $\mathrm{E}$ (VE) play a crucial role in this context (Khan, 2011; Khan et al., 2012a; Attia et al., 2017). The efficacy of VC in eliminating the adverse impact of HS and increasing thermotolerance has been previously reported (Umar et al., 2010). Increasing thermotolerance can minimise mortality from HS and maintain animal productivity (Attia and Hassan, 2017). Generally, HS increases the metabolism and the excretion of minerals and vitamins, leading to aggravating a deficiency in vitamins and minerals (Khan et al., 2012a). Heat stress has also been shown to decrease blood ascorbic acid concentration (Khan, 2011). The metabolism of minerals and amino acids requires $\mathrm{VC}$, which, in turn, is needed for the biosynthesis of adrenaline and testosterone, collagen and 125 -dihydroxy vitamin D (Khan et al., 2012a). Ascorbic acid has been reported to be involved in the activation of immunity, body temperature regulation and production of leucocytes (Khan, 2011). Adequate dietary VC helps to alleviate the metabolic signs of stress and improve immunity and behaviour of birds and their productive performance (Daghir, 2008; Attia et al., 2009; Attia et al., 2011). Ascorbic acid also spares VE by transforming the oxidised form of $\alpha$-tocopherol back to $\alpha$-tocopherol (Attia et al., 2017; Attia et al., 2018). VC was shown to improve the semen quality of heat-stressed roosters (Nowaczewski and Knotecka, 2005).

Alpha-tocopherol (VE), the 'anti-sterility' vitamin, is a natural antioxidant that guards the cell membranes against oxidative injury caused by the destruction of lipoperoxides, and thus VE requirements must be met (Traber and Atkinson, 2007; Tufarelli and Laudadio 2016). VE is not only essential for the prevention of lipid peroxidation (Khan, 2011) but also boosts the function and proliferation of macrophages, lymphocytes and plasma cells against oxidative injury (Traber, 2007); thereby improving the quality of semen and fertility of boars during the high temperature season (Khan, 2011). Consequently, enriching semen and spermatozoa with antioxidants is a prerequisite for improving male fertility (Tran, et al., 2017). Interestingly, administering a diet of $100-400 \mathrm{mg} / \mathrm{kg}$ of $\mathrm{VE}$ has been shown to significantly elevate semen quality of roosters (Keskes-Ammaret al., 2003; Al-Zahrani et al., 2012; Alm El-Dein et al., 2013). Supplementation with $100 \mathrm{mg} / \mathrm{kg}$ VE (Biswas et al., 2009) and $200 \mathrm{mg} / \mathrm{kg}$ VE (Ebeid, 2012) has been shown to enhance the antioxidant status and reduce the peroxidation of lipids in the seminal plasma of chicken males exposed to HS (Khan et al., 2012a;b). Vitamin C significantly raised the serum total protein and globulin of laying hens exposed to HS, but significantly reduced serum glucose, cholesterol, HDL and triglycerides (Ezzat et al., 2011).

The VE and/or VC were shown to equally elevate lymphocyte numbers and leucocytes, reducing the heterophil/lymphocyte ratio $(\mathrm{p}<0.05)$ in quails, suggesting that $\mathrm{VC}$ or $\mathrm{VE}$ alone is adequate (Sahin et al., 2002). A combination of both VC and VE showed a greater effect on physiological traits than administering only one of the vitamins (Attia et al., 2017). The same authors added that vitamins $\mathrm{C}+\mathrm{E}$ induced a further increase in basophil, serum total protein and albumin than $\mathrm{VC}$ alone. Moreover, the in vivo antioxidant influence of VE may be greater than that of VC (Hoehler and Marquardt, 1996). There is insufficient literature on the influence of HS on semen quality when a combination of different antioxidants is administered and whether this would improve chickens' tolerance to HS and improve semen quality and fertility. Hence, this study aimed to determine the impact of $\mathrm{HS}$ and $\mathrm{VC}$ and/or VE fortification in feed on semen quality and fertility, biochemical and haematological profile, antioxidants status and the DNA of the jejunum and ilium of male chickens.

\section{MATERIALS AND METHODS}

The experimental protocol was approved by the scientific committee of Animal Production Research Institute under registration code no: 9-2-4-3-10-1. The committee recommended the care and good handling of the animals, keeping in mind their rights and their welfare and causing them minimal stress.

Forty-five, 32-week-old male chickens of the Mandarah a native breed of Egypt classified as dualpurpose breed [a cross between ${ }^{\top}$ Alex $\times$ ODokki-4 (Abd- El- Gawad et al., 1981)], with similar initial body weights, were allocated randomly amongst five treatment groups of nine males in each group, between 32 and 52 weeks of age. The males were individually housed in galvanised wire cages $(30 \times 50 \times 60 \mathrm{~cm})$, in batteries with standard dimensions, in an environmentallycontrolled lightproof house (close system-controlled for temperature, humidity and light). Each cage was provided with a manual feeder and with nipple drinkers. Free access to a mash basal diet and to water was provided. Common veterinary care practices were used for vaccination and for the medical programme. The roosters were illuminated with 16:8 h light-dark cycles.

The health care, housing conditions, indoor and outdoor temperature and relative humidity and light schedule were as reported by Attia et al. (2016). The roosters were reared (indoors), either at optimal environmental conditions of $22^{\circ} \mathrm{C}-24^{\circ} \mathrm{C}$ with a relative humidity $(\mathrm{RH})$ of $45 \%-55 \%$, serving as a thermoneutral group and fed a basal diet (Table 1), or under heat stress 
$\left(38^{\circ} \mathrm{C} \pm 1{ }^{\circ} \mathrm{C} ; 55 \%-65 \%\right.$ relative humidity) for 3 successive days a week, from 11.00 am to $15.00 \mathrm{pm}$ and returned to thermoneutral conditions thereafter. The outdoor temperature was $30.7^{\circ} \mathrm{C} \pm 0.47^{\circ} \mathrm{C}$, with a $\mathrm{RH}$ of $70.9 \% \pm 0.9 \%$. The aim of heat stress scheme (3 days only per week), is to keep similar heat stress condition to that naturally occurs as 2-5 days a wave usually seen followed by more or less period of thermoneutral, thus this heat stress design is similar to what is happening in nature. Roosters exposed to HS were allocated to four groups: roosters kept under HS and fed with a basal diet without $\mathrm{VC}, \mathrm{VE}$ and $\mathrm{VC}+\mathrm{VE}$ serving as unsupplemented HS control (Control). In the second group, roosters were kept under HS and fed with a basal diet (Table 1) supplemented with $200 \mathrm{mg} / \mathrm{kg}$ ascorbic acid (VC) (L-ascorbic acid; a heat-stabilised product, Hoffmann-La Roche, Switzerland). In the third group, roosters were kept under HS and were fed a basal diet, supplemented with $150 \mathrm{mg} / \mathrm{kg} \alpha$-tocopherol acetate (VE) ( $\alpha$-tocopherol acetate, Hoffmann-La Roche, Switzerland). In the fourth group, roosters were kept under HS and were fed a basal diet, fortified with $200 \mathrm{mg} / \mathrm{kg} \mathrm{VC}$ and $150 \mathrm{mg} / \mathrm{kg} \mathrm{VE}(\mathrm{VC}+\mathrm{VE})$. The vitamins content of the basal diet particularly the total VE by calculation $(20.5$ $\mathrm{mg} / \mathrm{kg}$ ) were in according to the NRC (1994).

The roosters were individually weighed, at 32 and 52 weeks of age, and the body weight gain was calculated on the basis of the differences between the initial and the final body weight. Daily feed intake (g/cock) and mortality were recorded for each treatment.

Semen was collected weekly from all roosters after 10 weeks on the treatments, at 42 weeks of age and maintained for another 10 weeks, to determine the quality of the semen. Collection of semen was performed utilising the procedure of abdominal massage. The internal temperature of the semen at collection time was kept around $41^{\circ} \mathrm{C}-44^{\circ} \mathrm{C}$, using a water bath, and then the semen samples were transferred immediately to the laboratory after collection, to determine the quality of the spermatozoa. Moreover, attention was given so that the semen would be guarded from cold shocks and from direct light. Throughout the course of the semen collection, the time, place of collection and collector were constant. Semen quality included ejaculate volume (ml), sperm concentration $\left(\times 10^{9}\right.$ sperm $), \quad$ sperm concentrate/ejaculate $\left(\times 10^{9}\right.$ sperm $)$, sperm motility $(\%)$, sperm liveability $(\%)$, total live sperm/ejaculate $\left(\times 10^{9}\right.$ sperm), and semen $\mathrm{pH}$ were determined as outlined by Attia et al. (2015) and Attia and Kamel (2012), whereas semen quality factor was estimated according to Liuet al. (2008).

At 44, 48 and 52 weeks of age, the fertility of the roosters was measured. Semen was artificially collected by abdominal massage and was used for the artificial insemination of hens. Semen was used after 1:1 dilution, using a $0.9 \%$ saline solution as a diluent
(Bootwalla and Miles, 1992). The semen of each male was used to inseminate ten hens. Each hen was inseminated with $0.5 \mathrm{~mL}$ of semen, over 2 successive days. After 2 days of insemination, the eggs were collected over 10 days, stored at room temperature $\left(22^{\circ} \mathrm{C}\right.$ $-24^{\circ} \mathrm{C}$ with $\left.45 \%-55 \% \mathrm{RH}\right)$, incubated $\left(37.6^{\circ} \mathrm{C}, 55 \%\right.$ $\mathrm{RH})$ and hatched $\left(36.8^{\circ} \mathrm{C}, 65 \% \mathrm{RH}\right)$ in an automatic incubator, and the fertility was estimated by dividing the number of fertile eggs by the total number of eggs set.

At 52 weeks of age, blood samples $(5 \mathrm{~mL})$ were withdrawn from the brachial vein of each treatment. Blood samples $(n=5)$ at each treatment were collected from the overnight-fasted roosters in the morning in tubes, with heparin as an anticoagulant agent. Blood plasma and seminal plasma were obtained by the centrifugation of the blood and semen, at $1500 \times \mathrm{g}$ for 20 minutes and kept at $-20^{\circ} \mathrm{C}$ until used for analysis.

Plasma and seminal plasma metabolites, seminal and blood plasma total antioxidant capacity (TAC) and malondialdehyde (MDA) were determined, as outlined by the manufacturer's recommendation, using diagnostic kits (Diamond diagnostics, 23 EL-Montazah St. Heliopolis, Cairo, Egypt, http://www.diamonddiagnostics.com). Blood plasma creatinine was measured using special kits delivered from N.S. BIOTEC (http://www.nsbiotec.com). The aspartate aminotransferase (AST) and alanine aminotransferase (ALT) as (U/L) in the blood and seminal plasma were measured using available kits manufactured by Pasteur Lab (http://www.pasteurvetlab.com). Blood plasma alkaline phosphatase (ALP) was measured according to the method of Yan et al. (DGKC), (1972). Seminal plasma $\alpha-$ ,$\beta$ - and $\gamma$-globulin were determined using commercial ELISA, according to Bianchi et al. (1995).

Blood haemoglobin ( $\mathrm{Hgb} ; \%)$, were determined according to the method by Tietz (1982). Red blood cells (RBCs) were determined according to the method of Helper (1966), as well as that of Hawkeye and Dennett (1989). Packed cell volume (PCV; \%) was measured according to Wintrobe's method (1965). The mean cell volume (MCV), the mean cell haemoglobin $(\mathrm{MCH})$ and the mean cell haemoglobin concentration (MCHC) were estimated as absolute values, as reported by Attia et al. (2015). Phagocytic activity (PA) and phagocytic index (PI) were determined according to Kawaharaet al. (1991). White blood cells (WBCs) were determined as reported by Helper (1966) and Hawkeye and Dennett (1989), using a light microscope at $100 \times$ magnification. Blood film was prepared according to the method by Lucky (1977), to determine different leucocytes.

High molecular weight DNA was extracted from intestinal parts (jejunum and ileum), according to the method by Sambrook et al.(1989), with some modification following Abdel-Fattah (1995). The concentration of DNA was calculated on the basis of the optical density (O.D.) reading of the UV 
spectrophotometer, at a wave length of $260 \mathrm{~nm}$ (1.0 O.D. $=50 \mu \mathrm{g} \mathrm{DNA} / \mathrm{mL}$ of solution), according to Charles (1970).

The data were tested using the GLM procedure of $\mathrm{SAS} \circledast$ (SAS, 2011), and a one-way ANOVA, according to the following model: yij $=\mu+\tau j+\varepsilon i j$, where $\mu=$ the general mean, $\tau j=$ the effect of treatment and $\varepsilon i j=$ the experimental error. $A P \leqslant 0.05$ value of significance of student Newman Klaus' test was used for testing mean differences amongst the experimental groups, at $\mathrm{P} \leqslant 0.05$. Before the analysis, all the percentages were subjected to a logarithmic transformation to normalise the distribution of the data.

\section{RESULTS}

The HS significantly decreased body weight (BW) gain and feed intake of roosters, compared with roosters in the thermoneutral group (Table 2). The fortification with vitamins resulted in a similar partial recovery in $\mathrm{BW}$ gain. Vitamins induced a partial recovery in feed intake, with $\mathrm{VC}+\mathrm{VE}$ causing a greater response in feed intake than either $\mathrm{VC}$ or $\mathrm{VE}$ alone.

The exposure of roosters to HS without added vitamins significantly reduced ejaculate volume, sperm concentration, sperm concentration per ejaculate, sperm motility, sperm liveability, total live sperm per ejaculate, semen quality factor and fertility, but increased semen $\mathrm{pH}$ (Table 2).

The addition of vitamins resulted in a complete recovery in terms of sperm liveability, semen $\mathrm{pH}$ and fertility, compared with the thermoneutral group (Table 2). In addition, VE with or without VC caused a complete recovery of sperm concentration, compared with the thermoneutral group, but $\mathrm{VC}$ alone induced a partial recovery; however, the differences among the three vitamin groups were not significant.

A partial recovery due to the addition of vitamins to the HS group was shown in terms of the volume of the ejaculate, the concentration of sperm per ejaculate, the motility of the sperm, the total live sperm per ejaculate and the semen quality factor, compared with the thermoneutral group. The HS significantly modified seminal plasma total protein, the globulin, AST, ALT, TAC and MDA, compared with the thermoneutral group. On the other hand, seminal plasma albumin, different immunoglobulins, albumin/globulin ratio and AST/ALT ratio were not affected (Table 2).

Vitamin fortifications resulted in a complete recovery in terms of seminal plasma total protein, globulin, TAC and MDA, compared with the thermoneutral group, but only the combination of $\mathrm{VC}+$ $\mathrm{VE}$ resulted in a significantly higher plasma total protein and globulin, than the unsupplemented HS group (Table 2). In addition, vitamins fortifications resulted in a significantly higher TAC than in the thermoneutral group. Additional vitamins induced a partial recovery in ALT, but $\mathrm{VE}$ with or without $\mathrm{VC}$ resulted in a complete recovery in plasma AST, compared with the thermoneutral group, showing a stronger effect of VE than $\mathrm{VC}$, which induced a partial recovery in seminal plasma AST (Table 2).

Exposure to HS significantly impaired most of the biochemical constituents and jejunum and ilium DNA, except for blood globulin and the urea/creatinine ratio (Table 3 ).

Additional vitamins caused a complete recovery in plasma glucose, total lipids, triglycerides, cholesterol, ALT, AST/ALT ratio, creatinine, urea, TAC and MDA. $\mathrm{VC}$ and $\mathrm{VC}+\mathrm{VE}$ resulted in a complete recovery in the total plasma protein, thus the difference from the thermoneutral group disappeared, while $\mathrm{VC}+\mathrm{VE}$ had a greater effect than VE alone (Table 3). Vitamins $\mathrm{C}+\mathrm{E}$ induced a complete recovery in plasma albumin, $\mathrm{A} / \mathrm{G}$ ratio, AST and alkaline phosphatase, while $\mathrm{VC}$ and $\mathrm{VE}$ induced a partial recovery. $\mathrm{VC}+\mathrm{VE}$ resulted in a higher TAC than the VC or VE separately and the thermoneutral group (Table 3 ).

\section{Table 1. Ingredients and nutrient compositions of the experimental basal diet.}

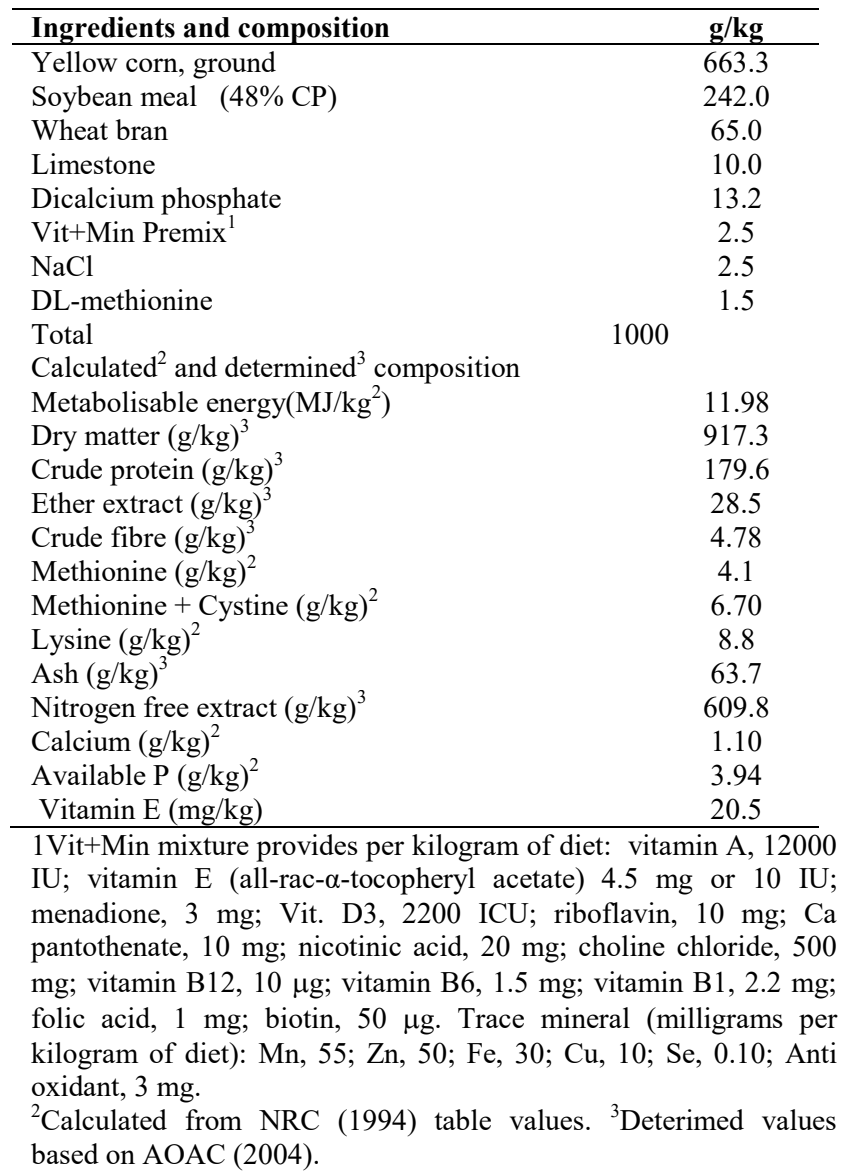


Additional vitamins significantly increased the DNA concentrations in both intestinal segments, compared with the unsupplemented HS group (Table 4). Additional $\mathrm{VC}$ resulted in a complete recovery in jejunum and ilium DNA, and $\mathrm{VC}+\mathrm{VE}$ caused a complete recovery in the ileum DNA. VC had a greater effect than VE on jejunum and ilium DNA.

Exposing roosters to HS significantly impaired most of the haematological constituents of blood, excluding $\mathrm{MCV}, \mathrm{MCH}, \mathrm{MCHC}$, basophils and eosinophils (Table 4). Vitamin fortification resulted in a complete recovery in $\mathrm{RBCs}, \mathrm{Hgb}, \mathrm{PCV}$ and WBCs. fortification with $\mathrm{VC}$ and $\mathrm{VE}$ induced a complete recovery in blood $\mathrm{pH}$, thus the difference with the thermoneutral group was diminished, but $\mathrm{VC}+\mathrm{VE}$ resulted in a partial recovery (Table 4). Phagocyte activity and monocytes were totally recovered when $\mathrm{VE}$ was supplemented, but $\mathrm{VC}$ and $\mathrm{VC}+\mathrm{VE}$ had a lower effect on monocytes than VE. Additional intake of vitamins resulted in incomplete PI and lymphocytes. Additional $\mathrm{VE}$ and $\mathrm{VC}+\mathrm{VE}$ resulted in a total recovery in the heterophil and $\mathrm{H} / \mathrm{L}$ ratio, thus the differences from the thermoneutral group was diminished (Table 4).

Table 2. Effects of dietary vitamin C (VC), vitamin E(VE), and their combined fortification on performance, semen quality and some seminal plasma constituents in roosters reared under heat stress condition $(\operatorname{mean} \pm$ SEM).

\begin{tabular}{|c|c|c|c|c|c|c|c|}
\hline \multirow[t]{2}{*}{ Parameters } & \multirow[t]{2}{*}{ Thermoneutral } & \multicolumn{4}{|c|}{ Heat stress treatments } & \multirow[t]{2}{*}{ SEM } & \multirow{2}{*}{$\begin{array}{c}\text { p- } \\
\text { value }\end{array}$} \\
\hline & & Heat stress & $+\mathrm{VC}$ & $+\mathrm{VE}$ & $+V C+V E$ & & \\
\hline \multicolumn{8}{|l|}{ Performance of roosters } \\
\hline Initial BW (g) & 2141 & 2128 & 2123 & 2118 & 2121 & 22.4 & 0.834 \\
\hline Body weight gain (g) & $513^{\mathrm{a}}$ & $401^{\mathrm{c}}$ & $463^{\mathrm{b}}$ & $455^{\mathrm{b}}$ & $473^{\mathrm{b}}$ & 15.7 & 0.001 \\
\hline Feed intake (g/bird/d) & $136^{\mathrm{a}}$ & $123^{\mathrm{d}}$ & $131 b^{c}$ & $129^{\mathrm{c}}$ & $133^{\mathrm{b}}$ & 1.11 & 0.001 \\
\hline \multicolumn{8}{|l|}{ Semen quality } \\
\hline Ejaculate volume $(\mathrm{ml})$ & $0.561^{\mathrm{a}}$ & $0.431^{\mathrm{c}}$ & $0.525^{\mathrm{b}}$ & $0.532^{\mathrm{b}}$ & $0.523^{\mathrm{b}}$ & 0.011 & 0.001 \\
\hline Concentrate $/ \mathrm{ml}\left(\times 10^{9}\right.$ sperm $)$ & $2.76^{\mathrm{a}}$ & $2.11^{\mathrm{c}}$ & $2.60^{\mathrm{b}}$ & $2.67^{\mathrm{ab}}$ & $2.68^{\mathrm{ab}}$ & 0.055 & 0.001 \\
\hline $\begin{array}{l}\text { Concentrate/ejaculate } \\
\left(\times 10^{9} \text { sperm }\right)\end{array}$ & $1.55^{\mathrm{a}}$ & $0.917^{\mathrm{c}}$ & $1.37^{\mathrm{b}}$ & $1.42^{\mathrm{b}}$ & $1.41^{\mathrm{b}}$ & 0.039 & 0.001 \\
\hline Sperm motility (\%) & $90.8^{\mathrm{a}}$ & $78.9^{\mathrm{c}}$ & $88.3^{\mathrm{b}}$ & $88.5^{\mathrm{b}}$ & $88.6^{\mathrm{b}}$ & 0.848 & 0.001 \\
\hline Sperm liveability (\%) & $87.2^{\mathrm{a}}$ & $79.1^{\mathrm{b}}$ & $86.1^{\mathrm{a}}$ & $86.3^{\mathrm{a}}$ & $86.5^{\mathrm{a}}$ & 0.527 & 0.001 \\
\hline $\begin{array}{l}\text { Total live sperm/ejaculate } \\
\left(\times 10^{9} \text { sperm }\right)\end{array}$ & $1.35^{\mathrm{a}}$ & $0.728^{\mathrm{c}}$ & $1.18^{\mathrm{b}}$ & $1.22^{\mathrm{b}}$ & $1.22^{\mathrm{b}}$ & 0.035 & 0.001 \\
\hline Semen $\mathrm{pH}$ & $7.28^{\mathrm{b}}$ & $7.55^{\mathrm{a}}$ & $7.29^{\mathrm{b}}$ & $7.34^{\mathrm{b}}$ & $7.28^{\mathrm{b}}$ & 0.031 & 0.001 \\
\hline Semen quality factor & $1349^{\mathrm{a}}$ & $728^{\mathrm{c}}$ & $1177^{\mathrm{b}}$ & $1206^{\mathrm{b}}$ & $1217^{\mathrm{b}}$ & 36.4 & 0.001 \\
\hline Fertility $(\%)$ & $96.5^{\mathrm{a}}$ & $79.2^{\mathrm{b}}$ & $94.6^{\mathrm{a}}$ & $96.3^{\mathrm{a}}$ & $96.0^{\mathrm{a}}$ & 0.333 & 0.001 \\
\hline \multicolumn{8}{|l|}{ Seminal plasma constituents. } \\
\hline Total protein $(\mathrm{g} / \mathrm{dl})$ & $6.13^{\mathrm{a}}$ & $5.48^{\mathrm{b}}$ & $5.88^{\mathrm{ab}}$ & $5.78^{\mathrm{ab}}$ & $6.03^{\mathrm{a}}$ & 0.182 & 0.025 \\
\hline Albumin $(\mathrm{g} / \mathrm{dl})$ & 2.30 & 2.28 & 2.33 & 2.10 & 2.28 & 0.097 & 0.205 \\
\hline Globulin (g/dl) & $3.83^{\mathrm{a}}$ & $3.20^{\mathrm{b}}$ & $3.53^{\mathrm{ab}}$ & $3.68^{\mathrm{ab}}$ & $3.78^{\mathrm{a}}$ & 0.189 & 0.032 \\
\hline $\mathrm{A} / \mathrm{G}$ ratio & 0.604 & 0.651 & 0.662 & 0.576 & 0.602 & 0.052 & 0.091 \\
\hline$\alpha$ - globulin (g/dl) & 1.625 & 1.475 & 1.625 & 1.775 & 1.500 & 0.102 & 0.065 \\
\hline$\beta$ - globulin $(\mathrm{g} / \mathrm{dl})$ & 1.20 & 1.175 & 1.225 & 1.175 & 1.225 & 0.108 & 0.626 \\
\hline$\gamma$-globulin $(\mathrm{g} / \mathrm{dl})$ & 1.00 & 0.675 & 0.675 & 0.725 & 1.025 & 0.182 & 0.163 \\
\hline AST (U/L) & $41.3^{\mathrm{c}}$ & $51.8^{\mathrm{a}}$ & $45.0^{\mathrm{b}}$ & $43.0^{\mathrm{bc}}$ & $43.3^{\mathrm{bc}}$ & 1.27 & 0.001 \\
\hline $\operatorname{ALT}(\mathrm{U} / \mathrm{L})$ & $15.0^{\mathrm{c}}$ & $19.8^{\mathrm{a}}$ & $17.3^{\mathrm{b}}$ & $17.0^{\mathrm{b}}$ & $16.8^{\mathrm{b}}$ & 0.736 & 0.001 \\
\hline AST/ALT & 2.77 & 2.65 & 2.60 & 2.54 & 2.60 & 0.154 & 0.653 \\
\hline $\mathrm{TAC}(\mathrm{Mmol} / \mathrm{dl})$ & $409^{\mathrm{b}}$ & $324^{c}$ & $431^{\mathrm{a}}$ & $432^{\mathrm{a}}$ & $435^{\mathrm{a}}$ & 6.32 & 0.001 \\
\hline MDA (Mmol/dl) & $0.925^{\mathrm{ab}}$ & $1.10^{\mathrm{a}}$ & $0.800^{\mathrm{b}}$ & $0.775^{\mathrm{b}}$ & $0.728^{\mathrm{b}}$ & 0.100 & 0.014 \\
\hline
\end{tabular}


Table 3. Effects of dietary vitamin C (VC), vitamin E (VE), and their combined fortification on some blood biochemical constituents, antioxidants status, and deoxyribonucleic in jejunum and ilium of roosters reared under heat stress condition (mean \pm SEM).

\begin{tabular}{|c|c|c|c|c|c|c|c|}
\hline \multirow[t]{2}{*}{ Parameters } & \multirow{2}{*}{ Thermoneutral } & \multicolumn{4}{|c|}{ Heat stress treatment } & \multirow{2}{*}{ SEM } & \multirow{2}{*}{ P-value } \\
\hline & & Heat stress & $+\mathrm{VC}$ & $+\mathrm{VE}$ & $+\mathrm{VC}+\mathrm{VE}$ & & \\
\hline Glucose $(\mathrm{mg} / \mathrm{dl})$ & $228^{\mathrm{a}}$ & $210^{\mathrm{b}}$ & $224^{\mathrm{a}}$ & $219^{\mathrm{a}}$ & $225^{\mathrm{a}}$ & 3.20 & 0.001 \\
\hline Total protein $(\mathrm{g} / \mathrm{dl})$ & $5.92^{\mathrm{a}}$ & $5.13^{\mathrm{c}}$ & $5.56^{\mathrm{ab}}$ & $5.40^{\mathrm{bc}}$ & $5.76^{\mathrm{a}}$ & 0.127 & 0.001 \\
\hline Albumin $(\mathrm{g} / \mathrm{dl})$ & $2.64^{\mathrm{a}}$ & $1.82^{\mathrm{c}}$ & $2.32^{\mathrm{b}}$ & $2.24^{\mathrm{b}}$ & $2.58^{\mathrm{a}}$ & 0.057 & 0.001 \\
\hline Globulin $(\mathrm{g} / \mathrm{dl})$ & 3.28 & 3.32 & 3.33 & 3.16 & 3.20 & 0.133 & 0.743 \\
\hline $\mathrm{A} / \mathrm{G}$ ratio & $0.803^{\mathrm{a}}$ & $0.550^{\mathrm{c}}$ & $0.698^{\mathrm{b}}$ & $0.710^{\mathrm{b}}$ & $0.815^{\mathrm{a}}$ & 0.119 & 0.001 \\
\hline Total lipids $(\mathrm{g} / \mathrm{dl})$ & $4.42^{\mathrm{b}}$ & $5.54^{\mathrm{a}}$ & $4.53^{\mathrm{b}}$ & $4.49 \mathrm{~b}$ & $4.48^{\mathrm{b}}$ & 0.191 & 0.001 \\
\hline Triglycerides $(\mathrm{mg} / \mathrm{dl})$ & $150^{\mathrm{b}}$ & $175^{\mathrm{a}}$ & $155^{\mathrm{b}}$ & $158^{\mathrm{b}}$ & $156^{\mathrm{b}}$ & 3.62 & 0.001 \\
\hline Cholesterol (mg/dl) & $136^{\mathrm{b}}$ & $154^{\mathrm{a}}$ & $140^{\mathrm{b}}$ & $142^{\mathrm{b}}$ & $139^{\mathrm{b}}$ & 2.87 & 0.001 \\
\hline $\mathrm{AST}(\mathrm{U} / \mathrm{L})$ & $40.1^{\mathrm{c}}$ & $61.7^{\mathrm{a}}$ & $44.1^{\mathrm{b}}$ & $43.3^{\mathrm{b}}$ & $41.7^{\mathrm{bc}}$ & 1.13 & 0.001 \\
\hline $\operatorname{ALT}(\mathrm{U} / \mathrm{L})$ & $17.3^{\mathrm{b}}$ & $21.9^{\mathrm{a}}$ & $18.3^{\mathrm{b}}$ & $18.2^{\mathrm{b}}$ & $17.7^{\mathrm{b}}$ & 0.389 & 0.001 \\
\hline AST/ALT & $2.32^{\mathrm{b}}$ & $2.81^{\mathrm{a}}$ & $2.40^{\mathrm{b}}$ & $2.38^{\mathrm{b}}$ & $2.33^{\mathrm{b}}$ & 0.082 & 0.001 \\
\hline $\operatorname{ALP}(\mathrm{U} / 1)$ & $171^{\mathrm{d}}$ & $192^{\mathrm{a}}$ & $183^{\mathrm{b}}$ & $179^{\mathrm{bc}}$ & $176^{\mathrm{cd}}$ & 2.04 & 0.001 \\
\hline Creatinine $(\mathrm{mg} / \mathrm{dl})$ & $3.19^{\mathrm{b}}$ & $3.30^{\mathrm{a}}$ & $3.23^{\mathrm{ab}}$ & $3.20^{\mathrm{b}}$ & $3.22^{\mathrm{ab}}$ & 0.032 & 0.058 \\
\hline Urea $(\mathrm{mg} / \mathrm{dl})$ & $3.40^{\mathrm{b}}$ & $3.58^{\mathrm{a}}$ & $3.41^{\mathrm{b}}$ & $3.51^{\mathrm{ab}}$ & $3.42^{\mathrm{ab}}$ & 0.046 & 0.034 \\
\hline Urea/ creatinine ratio & 0.940 & 0.923 & 0.940 & 0.913 & 0.930 & 0.191 & 0.684 \\
\hline TAC $(\mathrm{Mmol} / \mathrm{dl})$ & $431^{\mathrm{c}}$ & $374^{\mathrm{d}}$ & $447^{\mathrm{b}}$ & $450^{\mathrm{b}}$ & $458^{\mathrm{a}}$ & 2.24 & 0.001 \\
\hline MDA (Mmol/dl) & $0.915^{\mathrm{b}}$ & $1.27^{\mathrm{a}}$ & $0.888^{\mathrm{b}}$ & $0.870^{\mathrm{b}}$ & $0.858^{\mathrm{b}}$ & 0.026 & 0.001 \\
\hline DNAJ $(\mu \mathrm{g} / \mathrm{ml})$ & $26.99^{\mathrm{a}}$ & $22.75^{\mathrm{d}}$ & $26.90^{\mathrm{a}}$ & $24.40^{\mathrm{c}}$ & $24.89^{\mathrm{b}}$ & 0.219 & 0.001 \\
\hline DNAI $(\mu \mathrm{g} / \mathrm{ml})$ & $25.20^{\mathrm{a}}$ & $20.20^{\mathrm{c}}$ & $25.17^{\mathrm{a}}$ & $23.00^{\mathrm{b}}$ & $24.70^{\mathrm{a}}$ & 0.316 & 0.001 \\
\hline
\end{tabular}

SEM: standard error of means; A/G ratio: albumin/globulin ratio; AST:aspartate amino transferase; ALT:alanine amino transferase; TAC:total antioxidant capacity; MAD: malondialdehyde;DNAJ: deoxyribonucleic acid jejunum, DNAI: deoxyribonucleic acid ilium

${ }_{a, b, c}$ Means in the same row having different superscripts are significantly different $(\mathrm{P}<0.05)$.

Table 4. Effects of dietary vitamin C (VC), vitamin E (VE), and their combined fortification on some blood hematological parameters, some immunological indices, and differential leukocyte in roosters reared heat stress condition (mean \pm SEM).

\begin{tabular}{|c|c|c|c|c|c|c|c|}
\hline \multirow{2}{*}{$\begin{array}{c}\text { p- } \\
\text { Value }\end{array}$} & \multirow{2}{*}{ SEM } & \multicolumn{4}{|c|}{ Heat stress treatments } & \multirow{2}{*}{ SEM } & \multirow{2}{*}{$\begin{array}{c}\text { p- } \\
\text { Value }\end{array}$} \\
\hline & & Heat stress & $+\mathrm{VC}$ & $+\mathrm{VE}$ & $+\mathrm{VC}+\mathrm{VE}$ & & \\
\hline \multicolumn{8}{|l|}{ Hematological parameters } \\
\hline $\operatorname{RBCs}\left(\times 10^{6} / \mathrm{mm}\right)^{3}$ & $1.52^{\mathrm{a}}$ & $1.25^{\mathrm{b}}$ & $1.58^{\mathrm{a}}$ & $1.42^{\mathrm{a}}$ & $1.45^{\mathrm{a}}$ & 0.070 & 0.001 \\
\hline $\mathrm{Hgb}(\mathrm{g} / \mathrm{d} 10$ & $10.7^{\mathrm{a}}$ & $8.50^{\mathrm{b}}$ & $10.6^{\mathrm{a}}$ & $10.5^{\mathrm{a}}$ & $10.0^{\mathrm{a}}$ & 0.427 & 0.001 \\
\hline $\operatorname{PCV}(\%)$ & $32.7^{\mathrm{a}}$ & $26.5^{\mathrm{b}}$ & $32.5^{\mathrm{a}}$ & $30.7^{\mathrm{a}}$ & $31.0^{\mathrm{a}}$ & 1.09 & 0.001 \\
\hline $\operatorname{MCV}\left(\mu \mathrm{m}^{3} /\right.$ red blood cell $)$ & 215 & 214 & 206 & 218 & 216 & 14.14 & 0.919 \\
\hline $\mathrm{MCH}(\mathrm{pg} / \mathrm{dl})$ & 70.5 & 68.6 & 67.6 & 74.7 & 69.4 & 4.36 & 0.534 \\
\hline $\mathrm{MCHC}(\%)$ & 32.7 & 32.2 & 32.8 & 34.2 & 32.4 & 1.48 & 0.681 \\
\hline Blood pH & $7.54^{\mathrm{c}}$ & $7.76^{\mathrm{a}}$ & $7.57^{\mathrm{bc}}$ & $7.59^{\mathrm{bc}}$ & $7.61^{\mathrm{b}}$ & 0.021 & 0.001 \\
\hline \multicolumn{8}{|l|}{ Immunological traits } \\
\hline $\mathrm{PA}(\%)$ & $20.0^{\mathrm{a}}$ & $15.83^{\mathrm{c}}$ & $17.50^{\mathrm{bc}}$ & $19.17^{\mathrm{ab}}$ & $17.67^{\mathrm{bc}}$ & 0.837 & 0.001 \\
\hline PI $(\%)$ & $1.73^{\mathrm{a}}$ & $1.23^{\mathrm{c}}$ & $1.48^{\mathrm{b}}$ & $1.58^{\mathrm{b}}$ & $1.42^{\mathrm{b}}$ & 0.072 & 0.001 \\
\hline \multicolumn{8}{|c|}{ White blood cell counts and differential leukocyte } \\
\hline WBCs $\left(\times 10^{3} / \mathrm{mm}\right)$ & $26.3^{\mathrm{a}}$ & $22.5^{\mathrm{b}}$ & $24.7^{\mathrm{a}}$ & $24.8^{\mathrm{a}}$ & $26.0^{\mathrm{a}}$ & 0.663 & 0.001 \\
\hline Lymphocyte (\%) & $47.8^{\mathrm{a}}$ & $43.3^{c}$ & $45.5^{\mathrm{b}}$ & $45.8^{\mathrm{b}}$ & $46.5^{\mathrm{b}}$ & 0.490 & 0.001 \\
\hline Monocyte $(\%)$ & $6.83^{\mathrm{ab}}$ & $7.50^{\mathrm{ab}}$ & $6.50^{\mathrm{b}}$ & $8.00^{\mathrm{a}}$ & $6.50^{\mathrm{b}}$ & 0.508 & 0.024 \\
\hline Basophil (\%) & 0.500 & 0.500 & 0.500 & 0.833 & 0.500 & 0.302 & 0.745 \\
\hline Eosinophil (\%) & 9.50 & 9.33 & 9.50 & 9.33 & 10.17 & 0.572 & 0.579 \\
\hline Heterophil(\%) & $35.3^{\mathrm{c}}$ & $39.3^{\mathrm{a}}$ & $38.0^{\mathrm{ab}}$ & $36.0^{\mathrm{bc}}$ & $36.3^{\mathrm{bc}}$ & 0.909 & 0.001 \\
\hline $\mathrm{H} / \mathrm{L}$ ratio & $0.739^{c}$ & $0.909^{\mathrm{a}}$ & $0.835^{\mathrm{b}}$ & $0.786^{\mathrm{bc}}$ & $0.782^{b c}$ & 0.025 & 0.001 \\
\hline
\end{tabular}




\section{DISCUSSION}

HS has negative effects on both animal and human welfare. The use of antioxidants to relieve the negative effects of HS is important in animal and human nutrition (Attia et al., 2018; Kutluet al., 2019). In this study, we showed that HS negatively affects fertility and semen quality, while vitamin fortification shows promising relieving effects. High $\mathrm{H} / \mathrm{L}$ in roosters exposed to HS indicated the low welfare of roosters (McDaniel, 2004; Khan et al., 2012a;b). Similarly, H/L appears to be a more reliable indicator for stress and welfare in poultry (Aberra, 2011), which has adverse effects on animal immunity (Attia et al., 2009; Attia et $a l ., 2011)$. The decrease in TAC and the increase in MDA shown herein indicated the stressor effect of HS on the antioxidant status of roosters (Sahin et al. 2002). The MDA was higher in the spleen, thymus and bursa of the HS-exposed chicks than in those of the control one (Zhao et al., 2014).

Blood metabolites and immune indices were negatively affected by HS, showing a decrease in total protein in seminal and blood plasma, blood plasma albumin (non-specific immune protein), $\gamma$-globulin (innate immunity), PA and PI (non-specific immunity), WBCs and lymphocytes (cell-mediated immunity) and DNA of the intestinal segments. In addition, RBCs, Hgb concentration and PCV were adversely affected due to HS, showing low welfare and health of the animals. This could be attributed to the decline in the RBCs and thus oxygen carrying capacity causing less metabolic heat loss. Similarly, HS decreased $\mathrm{Hgb}$ and PCV and increased blood pH (Toyomizu et al., 2005; Daghir, 2008). This was concurred with a loss of ionic $\mathrm{Ca}$ (Sandercock et al., 2001), low availability of nutrients that are essential for DNA synthesis, function and repair (Habashy et al., 2017a; Habashy et al., 2017b) and increase in water intake (Attia et al., 2009; Attia et al., 2011).

There was a decrease in the semen quality and fertility traits of roosters exposed to HS, and this was associated with the reduction in feed intake of this group, as reported by Hood (1999) and McDaniel et al. (2004), who showed that $\mathrm{HS}$ of $>31^{\circ} \mathrm{C}$ depressed rooster sperm motility, viability and fertilisation potential. The declining fertility of heat-stressed males could be attributed to a decrease in sperm motility and the number of spermatozoa stored in the sperm host gland of laying hens (Brillard, 2003; Khan et al., 2012a;). In addition, HS can negatively affect testosterone, causing hypertrophy and weakening of the Leydig cell function (Stone and Seamark, 1984). The damaged DNA of sperm can increase abnormality, which could cause low fertility and subsequently could lead to reduced embryo survival (Sutovsky, 2015; Peña, et al., 2016; Zheng et al., 2018).
The results indicate that the improved semen quality, along with metabolic and haematological improvements and that of DNA of the intestinal segments of roosters exposed to $\mathrm{HS}$ and receiving diets fortified with dietary $\mathrm{VC}, \mathrm{VE}$ or $\mathrm{VC}+\mathrm{VE}$ agrees with the improved TAC and MDA in vitamin- fortified groups. This could be attributed to $6.5 \%, 4.9 \%$ and $8.1 \%$ increase in the feed intake of $\mathrm{VC}, \mathrm{VE}$ and $\mathrm{VC}+\mathrm{VE}$ groups, respectively; hence increasing the intakes of $\mathrm{VC}$ and $\mathrm{VE}$. Similarly, chickens receiving 200-400 mg/kg VC (Jacob, 1995) and VC and VC + VE (Attia et al., 2017) increased survival rate and feed intake.

In the literature, VC improved chickens' thermotolerance (Umar et al., 2010; Khan, 2011; Attia et $a l ., 2018)$ and this can mimic mortality from HS and can maintain animal productivity (Attia et al., 2011;Daghir, 2008). A marginal deficiency of vitamins and minerals may have occurred due to HS exposure, as a result of increasing utilisation and excretion of vitamins and minerals from tissues (Khan et al., 2012a;b), and decreasing blood ascorbic acid (Khan, 2011; Attia et al., 2016;). In addition, VC is essential for amino acids and mineral metabolism, collagen, 1, 25-dihydroxy vitamin $\mathrm{D}$, biosynthesis of testosterone and adrenaline (Khan et al., 2012a;b), secretion of corticosterone, leukocyte production and immune system activation (Daghir, 2008; Attia et al., 2016;Attia et al., 2017).

Fortification with VE above the recommended dose (5 mg/kg diet; NRC, 1994) to $150 \mathrm{mg} / \mathrm{kg}$ diet shows a similar effect to $\mathrm{VC}$ on most of investigated traits except that $\mathrm{VE}$ has a stronger effect on monocyte (macrophages) and $\mathrm{H} / \mathrm{L}$ ratio than $\mathrm{VC}$, but a lower influence on the DNA of the jejunum and ilium. VE guards cells and tissues from lipoperoxidative injury caused by ROS and preclude the lipid peroxidation of spermatozoa from oxidative damage (Khan, 2011; Tufarelli and Laudadio, 2016). Interestingly, addition of 100 and $150 \mathrm{mg} / \mathrm{kg}$ diet of VE significantly increased semen quality, compared with roosters on both 15 and 75 $\mathrm{mg} / \mathrm{kg}$ VE groups (Al-Zahrani et al., 2012; Alm El-Dein et al., 2013). VE guards lymphocytes, macrophages and plasma cells against oxidative injury, boosting their function and proliferation (Traber, 2007). A dose of 250 $\mathrm{mg} / \mathrm{kg}$ diet VE was found to be ideal for partly easing the negative effect of $\mathrm{HS}$ and improve productivity and immunity of chickens (Çiftçi et al., 2005; Mohiti-Asli et al., 2010;).

The enhancing impact of $\mathrm{VE}$ on fertility reflected the results of sperm motility, liveability and semen quality factor. In addition, fertility found herein was numerically higher $(\approx 1.7 \%)$ in the $\mathrm{VE}$ and $\mathrm{VC}+\mathrm{VE}$ groups, than in the $\mathrm{VC}$ group alone. In concert with the present results, a $100 \mathrm{mg} / \mathrm{kg}$ VE was found to be the best for maintained the fertility in male chickens (KeskesAmmar et al., 2003). Similarly, Hoehler and Marquardt (1996) showed that the in vivo antioxidant influence of 
$\mathrm{VE}$ might be greater than that of $\mathrm{VC}$, but was adequate for relieving HS in quails (Ipek et al., 2007). In male chickens, however VC of $250 \mathrm{mg}$ and VE up to 200 $\mathrm{mg} / \mathrm{kg}$ can boost semen quality and fertility (Khan et al., 2012a).

A synergistic effect of $\mathrm{VC}+\mathrm{VE}$ was observed in feed intake, blood plasma albumin (non-specific immune-protein), A/G ratio and blood plasma TAC, as $\mathrm{VC}+\mathrm{VE}$ surpassed the effect of VC or VE alone, which can explain the superior performance of roosters on $\mathrm{VC}$ $+\mathrm{VE}$ treatment. In addition, $\mathrm{VC}+\mathrm{VE}$ had lower monocytes than VE alone, but higher blood plasma total protein and intestinal DNA, and lower ALP and jejunum DNA than VC alone. Similarly, VC and VE had a synergistic influence for decreasing the negative impact of HS as VC defends VE from peroxidation (Sahin et al., 2002). Obviously, VC or VE were less effective than VC $+\mathrm{VE}$ (Attia et al., 2017), and VC + VE delayed the oxidation of myoglobin (Yin et al., 1993). Furthermore, $\mathrm{VC}$ enhanced VE antioxidant power by decreasing the tocopheroxyl radicals back to their active formula of $\mathrm{VE}$, or by sparing the available VE (Jacob, 1995).

The increase in antioxidant intakes resulted in $33.0 \%, 33.3 \%$ and $34.3 \%$ increases in seminal plasma TAC, in the HS exposed roosters whose feed had been supplied with VC, VE and VC+VE and 19.5, 20.3 and $22.5 \%$ in blood plasma TAC, respectively, as compared with the unsupplemented HS group. The results demonstrated a symbiotic effect between the two vitamins in blood plasma TAC and in the concentration in blood levels which was higher than cellular levels. This may be due to the crucial role of antioxidants in the cell defence system (Attia et al., 2017; Kutlu et al., 20019). Further evidence was found in the reduction in the MDA in seminal plasma, which amounted to 27.3, 29.5 and $33.8 \%$ and in blood plasma, which amounted to $30.1,31.5$ and $32.4 \%$ respectively, due to $\mathrm{VC}, \mathrm{VE}$ and $\mathrm{VC}+\mathrm{VE}$. These results are in line with those reported by Khan et al. (2012a), Attia et al. (2016) and Attia et al. (2017). Likewise, VC was found to boost the semen quality of heat-stressed roosters as reported by Nowaczewski and Knotecka (2005) and Ezzat et al. (2011). However, the beneficial of VC on semen quality remains contradictory (McDaniel et al., 2004), maybe due to the oxidative degradation of VC (Mckee and Harrison, 1995); thus Khan et al. (2012a;b) concluded that the effect of VC on semen quality is dose-specific.

Conclusions: Either $\mathrm{VC}$ of $200 \mathrm{mg} / \mathrm{kg}$ or $\mathrm{VE}$ of 150 $\mathrm{mg} / \mathrm{kg}$ can significantly improve semen quality, fertility, or physiological of roosters reared under HS, with the VE group yielding greater immunity. In addition, $\mathrm{VC}+\mathrm{VE}$ surpassed the influence of $\mathrm{VC}$ or $\mathrm{VE}$ alone on feed intake, blood plasma albumin, albumin/globulin ratio and blood plasma TAC, showing a synergetic effect of $\mathrm{VC}+$ VE. Moreover, VC + VE decreased monocytes compared with VE alone, but increased blood plasma total protein and DNA in jejunum and ilium and lowered blood alkaline phosphatase, compared with VC.

Acknowledgements: This article was funded by the deanship of scientific Research (DSR) at King Abdulaziz University, Jeddah. The authors, therefore, acknowledge with thanks DSR for technical and financial support.

\section{REFERENCES}

Abd EI-Gawad, Elham, M. (1981). The "Mandarah" a new breed of chickens. Egypt. Poult. Sci. J. 1: 16-22.

Alm El-Dein, A. K., M.M. Soliman, and S. Abd El-Aziz (2013). Effect of dietary vitamin E supplementation on some productive, reproductive and immunological traits of Inshas chickens strain. Egypt. Poult. Sci. J. 33: 939955.

Abdel-Fattah, A.F., E.H. Mohamed, and G. Ramadan (1995). Effect of thymus extract on immunologic reactively of chicken vaccinated with infectious bursal disease virus. J. Vet. Med. Sci. 61: 811-817.

Aberra, M. (2011). Performance and physiological responses of naked-neck chickens and their crosses with commercial layer breeds to longterm high ambient temperature. Global Veterinarian 6: 272-280.

Al-Zahrani, S., M. Mohany, S. Kandeal, and G. Badr (2012). Thymoquinone and vitamin $\mathrm{E}$ supplementation improve the reproductive characteristics of heat stressed male mice. J. Medicinal Plants Res. 6: 493-499.

Kutlu, H.R., S. N. Saber, H. Kutay, L. Çelik, F. Yenilmez, N. Toy, M. Kutlu, and O. Yücelt (2019). Effect of form of selenium used in broiler breeders' diet on egg production, egg quality, hatchability and chicks growth performance. The J. Anim \& Plant Sci. 29:5867.

Attia, Y.A., A.E. Abd El-Hamid, A.A. Abedalla, M.A. Berika, M.F. El-Gandy, K. Sahin, and B. M. Abou-Shehema (2018). Effect of betaine, vitamin $\mathrm{C}$, and vitamin $\mathrm{E}$ on egg quality, hatchability, and markers of liver and renal functions in dual-purpose breeding hens exposed to chronic heat stress. Europ. Poult. Sci. 82. DOI: 10.1399/eps.2017.171.

Attia, Y.A., E.A. Abd- El-Hamid, A.M. ElHanoun, M.A. Al-Harthi, G.M. Mansour, and M.M. Abdella (2015). Responses of the fertility, semen quality, blood constituents, immunity and antioxidant status of rabbit bucks to type and 
magnetizing of water. Annals Anim. Sci. 15: 387-407

Attia, Y.A., A.E. Abd El-Hamid, A.A. Abedalla, M.A. Berika, M.A. Al-Harthi, O. Kucuk, K. Sahin, and B.M. Abou-Shehema (2016). Laying performance, digestibility and plasma hormones in laying hens exposed to chronic heat stress as affected by betaine, vitamin $\mathrm{C}$, and/or vitamin $\mathrm{E}$ supplementation. Springerplus, 5:1619.doi: 10.1186/s40064-016-3304-0.

Attia, Y.A., M.A. Al-Harthi, A.S. El-Shafey, Y.A. Rehab, and W.K. Kim (2017). Enhancing tolerance of broiler chickens to heat stress by supplementation with vitamin $\mathrm{E}$, vitamin $\mathrm{C}$ and/or probiotics. Annals - Anim. Sci. 17: 1-15.

Attia, Y.A., R.A. Hassan, and M.A. Qota (2009). Recovery from adverse effects of heat stress on slow-growing chicks in the tropics 1: Effect of ascorbic acid and different levels of betaine. Tropic Anim. Health and Prod. 41:807-818.

Attia, Y.A., R.A. Hassan, A.E. Tag El-Din, and B.M. Abou-Shehema (2011). Effect of ascorbic acid or increasing metabolizable energy level with or without supplementation of some essential amino acids on productive and physiological traits of slow-growing chicks exposed to chronic heat stress. J. Anim. Physio. and Anim. Nutr. 95: 744-755.

Attia, Y. A. and K.I. Kamel (2012). Semen quality, testosterone level, seminal plasma biochemical profile and antioxidant statues of $\mathrm{V}$-line rabbit bucks supplemented with different levels of soybean lecithin. Anim. 6: 824-833.

Ayo, J.O., J.A. Obidi, and P. I. Rekwot (2011). Effects of heat stress on the well-being, fertility, and hatchability of chickens in the northern guinea savannah zone of Nigeria: A Review. ISRN Vet. Sci.

2011, http://dx.doi.org/10.5402/2011/838606.

Biswas, A., J. Mohan, and K.V. Sastry (2009). Effect of higher dietary vitamin $\mathrm{E}$ concentrations on physical and biochemical characteristics of semen in Kadaknath cockerels. Br. Poult. Sci. 50:733-738.

Bootwalla, S. M. and R. D. Miles (1992). Development of diluents for domestic fowl semen. World's Poult. Sci. J. 48: 121-128.

Bianchi, A.T.J., H.W.M. Moonen-Leusen, P.J.van der Heijden, and B.A. Bokhout (1995). The use of a double antibody sandwich ELISA and monoclonal antibodies for the assessment of porcine IgM, IgG, and IgA concentrations. Vet. Immun. Immunopathological 44: 309-317.

Brillard, J. P. (2003). Practical aspects of fertility in poultry. World's Poult. Sci. J. 59: 441-446.
Charles, P. (1970). Isolation of Deoxyribonucleic acid: Uptake of informative moleculas by living cells. Ledouix, L. Ed. North Holland Publishing Company, Amesterdam, London.

Chen, Z., J.R. Zhang, Y.W. Zhou, C. Liang, and Y.Y. Jiang (2015). Effect of heat stress on the pituitary and testicular development of Wenchang chicks. Arch. Anim. Breeding 58: 373-378.

Çiftçi, M., O. Nihat-Ertas, and T. Guler (2005). Effects of vitamin $\mathrm{E}$ and vitamin $\mathrm{C}$ dietary supplementation on egg production and egg quality of laying hens exposed to a chronic heat stress. Veterinarica 156: 107-111.

Conte, G., R. Ciampolini, M. Cassandro, E. Lasagna, L. Calamari, U. Bernabucci, and F. Abeni (2018). Feeding and nutrition management of heatstressed dairy ruminants. It. J. Anim. Sci. 17: 604-620.

Daghir, N. J. (2008). Poultry Production in Hot Climates, $2^{\text {nd }}$ Edition, Published by CAB International, Wallinford, Oxfordshire, UK, pp. 387

Ebeid, T.A. (2012). Vitamin E and organic selenium enhances the antioxidative status and quality of chicken semen under high ambient temperature. Br. Poult. Sci. 53:708-714.

Ezzat, W., M.S. Shoeib, S.M.M. Mousa, A.M.A. Bealish, and Z.A. Ibrahiem (2011). Impact of betaine, vitamin $\mathrm{C}$ and folic acid supplementation to the diet on productive and reproductive performance of Matrouh poultry strain under Egyptian summer condition. Egypt. Poult. Sci. J. 31: 521537.

Habashy, W.S., M.C. Milfort, K. Adomako, Y.A. Attia, R. Rekaya, and S.E. Aggrey (2017a). Effect of heat stress on amino acid digestibility and transporters in meat-type chickens. Poult. Sci. 96: 312-319.

Habashy, W.S., M.C. Milfort, A.L. Fuller, Y.A. Attia, R. Rekaya, and S. E. Aggrey (2017b). Effect of heat stress on protein utilization and nutrient transporters in meat-type chickens. Inter. J. Biomet 61: 2111-2118.

Hawkeye, C.M. and T.B. Dennett (1989). A color atlas of comparative veterinary hematology wolf publishing Limited, London, England.

Helper, O.E. (1966). Manual of clinical laboratory methods. Thomas Spring Field, Illinois, USA.

Hood, J. E. (1999). An attempt at alleviating heat stress infertility in male broiler breeder chickens with dietary ascorbic acid. MS Thesis, Mississippi State University, Mississippi State, MS, USA.

Hoehler, D. and R.R. Marquardt (1996). Influence of Vitamin $\mathrm{E}$ and $\mathrm{C}$ on the toxic effects of ochratoxin A and T-2 Toxin in chicks. Poult. Sci. 75: 1508-1515. 
Ipek, H., M. Avci, M. Yerturk, M. Iriadam, and N. Aydilek (2007). Effects of ascorbic acid and vitamin $\mathrm{E}$ on performance and hematological parameters of Japanese quails under high ambient temperature in Sanliurfa. Arch. für Geflügelk. 71: 130-134.

Jacob, R.A. (1995). The integrated antioxidant system. Nutritional Res. 15: 755-766.

Kawahara, E., T. Ueda, and S. Nomura (1991). In vitro phagocytic activity of white spotted shark cells after injection with Aermonassalmonicida extracellular products. Gyobokenkyu Japan 26: 213-214.

Khan, R.U., S. Naz, Z. Nikousefat, M. Selvaggi, V. Laudadio, and V. Tufarelli (2012a). Effect of ascorbic acid on heat -stressed Poultry. World's Poult. Sci. J. 68: 477-489.

Khan, R. U., Z. U. Rahman, I. Javed, and F. Muhammad (2012b). Effect of vitamins, probiotics and protein on semen traits in post-molt male broiler breeders. Anim. Reprod. Sci. 135: 85-90.

Khan, R.U., S. Naz, and K. Dhama (2014). Chromium: pharmacological applications in heat stressed poultry. Inter. J. of Pharmacology 10: 213-317.

Khan, R.U. (2011). Antioxidants and Poultry semen quality. World's Poult. Sci. J. 67: 297-308.

Keskes-Ammar, L., N. Feki-Chakroun, T. Rebai, Z. Sahnoun, H. Ghozzi, S. Hammami, K. Zghal, H. Fki, J. Damak, and A. Bahloul (2003). Sperm oxidative stress and the effect of an oral vitamin $\mathrm{E}$ and selenium supplement on semen quality in infertile men. J. Reprod. Sys. 49: 89-94.

Lucky, Z. (1977). Methods for the diagnosis of fish diseases. Ameruno Publishing Co, PVT, LTd. New Delhi, Bomby, NY.

Liu, S. J., J. X. Zheng, and N. Yang (2008). Semen quality factor as an indicator of fertilizing ability for geese. Poult. Sci. 87: 155-159.

McDaniel, C.D., J.E. Hood, and H.M. Parker (2004). An attempt at alleviating heat stress infertility in male broiler breeder chickens with dietary ascorbic acid. Inter. J. Poult. Sci. 3: 593-602.

McKee, J. S. and P.C. Harrison (1995). Effects of supplemental ascorbic acid on the performance of broiler chickens exposed to multiple concurrent stresses. Poult. Sci. 74: 1772-1785.

Mohiti-Asli, M., F. Shariatmadari, and H. Lotfollahian, (2010). The influence of dietary vitamin $\mathrm{E}$ and selenium on egg production parameters, serum and yolk cholesterol and antibody response of laying hen exposed to high environmental temperature. Archiv. für Geflügelk. 74: 43-50.

National Research Council, NRC. (1994). Nutrient Requirement of Poultry. National Academy Press, Washington, D. C., USA.
Nowaczewski, S. and H. Knotecka (2005). Effect of dietary vitamin $\mathrm{C}$ supplement on reproductive performance of aviary pheasants. Czech J. Anim. Sci. 50: 208-212.

Peña, S.T., B. Gummow, A.J. Parker, and D.B.B.P. Paris (2016). Revisiting summer in fertility in the pig; could heat stress- induced sperm DNA damage negatively affect early embryo development? Anim. Prod. Sci. 57: 1975-1983.

Sahin, K., N. Sahin, and S. Yaralioglu (2002). Effects of vitamin $\mathrm{C}$ and vitamin $\mathrm{E}$ on lipid peroxidation, blood serum metabolites, and mineral concentrations of laying hens reared at high ambient temperature. Biological Trace Element Res. 85: 35-45.

Sambrook, J., E. F. Fristsch, and M. Maniatis (1989). Molecular cloning A laboratory manual. $2^{\text {nd }} \mathrm{Ed}$. Cold Spring Harber Laboratory. Cold Spring Harber. NY.

Sandercock, D.A., R.R. Hunter, G.R. Nute, M.A. Mitchell, and P. M. Hocking (2001). Acute heat stress-induced alterations in blood acid-base status and skeletal muscle membrane integrity in broiler chickens at two ages: Implications for meat quality. Poult. Sci. 80: 418-425.

SAS Institute, (2007). SAS User's Guide.SAS Institute Inc., Cary, NC.

Stone, B.A. and R.F. Seamark (1984). Effects of acute and chronic testicular hyper thermia on levels of testosterone and corticosteroids in plasma of boars. Anim. Reprod. Sci. 7: 391-403.

Surai, P.F., N. Fujihara, B.K. Speake, J.P. Brillard, G.J. Wishart, and N.H.C. Sparks (2001). Polyunsaturated fatty acids, lipid peroxidation and antioxidant protection in avian semen.Asian-Australian J. Anim. Sci. 14: 1024 1050.

Sutovsky, P. (2015). New approaches to boar semen evaluation, processing and improvement. Reprod. of Domestic Anim. 50: 11-19.

Tietz, N.W. (1982). Fundamental of clinical chemistry Edition by Norbert Sounder Company, Philadelphia, USA.

Toyomizu, M., M. Tokuda, A. Mujahid, and Y. Akiba (2005). Progressive alteration to core temperature, respiration and blood acid-base balance in broiler chickens exposed to acute heat stress. J. Poult. Sci. 42: 110-118.

Traber, M.G. and J. Atkinson (2007). Vitamin E antioxidant and nothing more. Free Radical Biology Med. 43: 4-15.

Tran, L.V., B. A. Malla, S. Kumar, and A.K. Tyagi (2017). Polyunsaturated fatty acids in male ruminant reproduction - A Review. AsianAustralian J. Anim. Sci. 30: 622-637. 
Turk, G., A.O. Ceribasy, U.G. SimsekCeribasy, S. Guvenc, S. Kaya, and M.Yaman (2016). Dietary rosemary oil alleviates heat stress-induced structural and functional damage through lipid peroxidation in the testes of growing Japanese quail. Anim. Reprod. Sci. 164: 133-143.

Umar, I.A., I. Toma, C.A. Akombum, C.J. Nnadi, M.A. Mahdi, A. Gidado, I. O. Igbokwe, and L.B. Buratai (2010). The role of intraperitoneally administered vitamin $\mathrm{C}$ during Trypanosoma congolense infection of rabbits. Afr. J. of Biotech. 9: 5224-5228.

Wintrobe, M.M. (1965). Clinical Hematology. $5^{\text {th }}$ edn, Lea, and Febiger Philadelphia, USA.

Yan, F., J.H. Kersey, C.A. Fritts, P.W. Waldroup, H.L. Stilborn, R.C., Crumm Jr., and D.W. Rice, DGKC(1972). Recommendations of the German Society for Clinical Chemistry, Z. Klin. Chimerical and Clinical. Biochemistry. 10:182.
Yin, M.C., C. Faustman, J.W. Riesen, and S. N. Williams (1993). Alpha-tocopherol and ascorbate delay oxymyoglobin and phospholipid oxidation in vitro. J. Food Sci. 58: 1273-1276.

Zaniboni, L., R. Rizzi, and S. Cerolini (2006). Combined effect of DHA and $\alpha$-tocopherol enrichment on sperm quality and fertility in the turkey. Theriogenology 65: 1813-1827.

Zhao, F.Q., Z.W. Zhang, J.P. Qu, H.D. Yao, M. Li, S. Li, and S.W. $\mathrm{Xu}$ (2014). Cold stress induces antioxidant and HSPs in chicken immune organs. Cell Stress Chaperones 19: 635-648.

Zheng, W.W., G. Song, Q.L. Wang, S.W. Liu, X.L. Zhu, S.M. Deng, A. Zhong, and Y. M. Tan (2018). Sperm DNA damage has a negative effect on early embryonic development following in vitro fertilization. Asian J of Andrology 20:75-79. 